\title{
Nutrient and phytoplankton dynamics in two mangrove tidal creeks of the Indus River delta, Pakistan
}

\author{
P. J. Harrison ${ }^{1, *}$, N. Khan ${ }^{2}$, K. Yin ${ }^{1}$, M. Saleem ${ }^{2}$, N. Bano ${ }^{2}$, M. Nisa ${ }^{2}$, S. I. Ahmed ${ }^{3}$, \\ N. Rizvi' ${ }^{2}$ F. Azam ${ }^{4}$ \\ 'Department of Earth \& Ocean Sciences, University of British Columbia, Vancouver, British Columbia, Canada V6T 1Z4 \\ ${ }^{2}$ National Institute of Oceanography, S.T. 47, Block 1, Clifton, Karachi, Pakistan \\ ${ }^{3}$ School of Oceanography, University of Washington, Seattle, Washington 98195, USA \\ ${ }^{4}$ Scripps Institution of Oceanography, UCSD, La Jolla, California 92093, USA
}

\begin{abstract}
We report the results of a 3 yr study on 2 tidal creeks in the northwest corner of the Indus River delta (Pakistan) mangrove ecosystem. We measured light (extinction coefficients), nutrients (nitrate, nitrite, phosphate, silicate and ammonium), chlorophyll a (chl a), suspended load, primary productivity $\left({ }^{14} \mathrm{C}\right.$ uptake) and phytoplankton species in Isaro and Gharo Creeks. There was no clear seasonal cycle in any of the 5 nutrients in either of the 2 tidal creeks. $\mathrm{NO}_{3}$ ranged from 1 to $8 \mu \mathrm{M}, \mathrm{NH}_{4}$ from 2 to $15 \mu \mathrm{M}, \mathrm{SiO}_{4}$ from 3 to $20 \mu \mathrm{M}$, and $\mathrm{PO}_{4}$ from 0.2 to $2 \mu \mathrm{M}$ (except when it was undetectable during a bloom in Isaro Creek in June). Hence, nitrogen and silicate do not limit primary productivity, but during a large bloom phosphate may become limiting. When phosphate samples were reanalyzed without removing the sediment (no filtration), phosphate concentrations were about $25 \%$ higher. This suggests that phosphate is adsorbed to sediment particles and could potentially be biologically available. There was a high suspended load (100 to $180 \mathrm{mg} \mathrm{l}^{-1}$ ) because the sediments were fine (silt and clay) and they were kept suspended by high tidal currents $\left(0.5\right.$ to $\left.1.5 \mathrm{~m} \mathrm{~s}^{-1}\right)$ caused by tidal ranges of up to $4 \mathrm{~m}$ during spring tides in these shallow ( 3 to $9 \mathrm{~m}$ deep) creeks. Hence, extinction coefficients were very high ( 1 to $2 \mathrm{~m}^{-1}$ ) and the $1 \%$ light depth ranged from $<1 \mathrm{~m}$ in August (the rainy season) to about $4 \mathrm{~m}$ in January and February. Consequently, primary productivity appeared to be light-limited throughout the year. $\mathrm{Chl}$ a ranged from 1 to $4 \mu \mathrm{g} \mathrm{l^{-1 }}$ with occasional blooms up to $40 \mu \mathrm{gl}^{-1}$. Primary productivity ranged from 0.2 to over $1 \mathrm{~g} \mathrm{C} \mathrm{m}^{-2} \mathrm{~d}^{-1}$ in Isaro Creek. There was no apparent seasonal cycle in chl $a$ or primary productivity. Phytoplankton species were predominantly large centric diatoms which were presumably kept in suspension by tidal currents. Since nutrients are rarely limiting, there is an export of nutrients from the creeks to the coastal area which may stumulate phytoplankton productivity.
\end{abstract}

KEY WORDS: Nutrients Phytoplankton Mangroves - Tidal creeks - lndus River delta - Seasonal cycle Primary productivity

\section{INTRODUCTION}

The Indus River is one of the world's largest rivers and it enters the Arabian Sea through a network of meandering distributaries and tidal spill rivers. Its delta in Pakistan occupies an area of 250000 ha (Khan 1966) and it ranks as the fifth or sixth largest single mangrove area in the world. This mangrove ecosystem is relatively unique because of the arid environment

•E-mail: pharrisn@unixg.ubc.ca surrounding it. The annual rainfall is very low (180 to $220 \mathrm{~mm}$ ) and most of this falls in July and August during the southwest monsoons.

Since there is some evidence that this mangrove ecosystem is showing signs of stress due to the lack of freshwater reaching the mangroves, a comprehensive study was initiated (PAKMER: Pakistan Mangrove Ecosystem Research). Previous studies on this mangrove ecosystem have been reviewed (Harrison et al. 1994) and the effect of the hypersaline environment on mangrove survival has been evaluated (Ahmed 1992). 
The seasonal cycles of biological parameters are usually driven by physical factors through processes referred to as physical-biological coupling. To better understand the biological observations presented in this paper, the salient physical factors of the tidal creeks will be briefly reviewed (see Harrison et al. 1994 for details).

The highest river discharge occurs in July due to the snow melt in the Himalayas. About $80 \%$ of the Indus River discharge occurs from May to October. The tidal creeks are often wide and long (often $>70 \mathrm{~km}$ ) and make up about $27 \%$ by area of the delta. Tidal heights during the main monthly spring tide range from 3.4 to $3.9 \mathrm{~m}$ and from 1.5 to $2.5 \mathrm{~m}$ during neap tides. Therefore the creeks are generally well mixed beyond the salt wedge at the mouth of the creeks. The largest spring tide of the year occurs in November and December.

The winds are light $\left(\sim 4 \mathrm{~m} \mathrm{~s}^{-1}\right)$ for most of the year (northeast winter monsoons), except in summers (southwest monsoons) when average wind speeds reach 8 to $9 \mathrm{~m} \mathrm{~s}^{-1}$. Many of the tidal channels lie along a SW-NE axis and they are 30 to $70 \mathrm{~km}$ long. As a result there is a considerable fetch and water is pushed up the tidal channels by the SW wind the maximum tidal height occurs in July which coincides with the maximum wind speed. Therefore, the maximum inundation by coastal seawater occurs in July during midday.

The physical oceanography of the Indus delta creeks and coastal waters is poorly understood. Except for the area near the discharge of the Indus River, a large part of the delta area is relatively unique in that it is a negative estuary since evapotranspiration

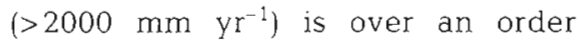
of magnitude greater than rainfall $\left(\sim 200 \mathrm{~mm} \mathrm{yr}^{-1}\right.$ ) (Schubel 1984). A second unique feature of this ecosystem is the reverse salt wedge at the mouth of the creeks. Consequently, inflow of the lighter $(-34 \%)$ coastal seawater into the creeks is at the surface and the denser ( 36 to $40 \%$ ) creek water flows out at depth. The SW monsoon winds in summer ( 8 to $9 \mathrm{~m} \mathrm{~s}^{-1}$ ) push the surface water up the creeks, increasing the flood tide at the surface. The NE monsoon winds in the winter and spring push the surface water downstream, thereby increasing the ebb at the surface. Since the rainfall is so low, it is expected that the residence time in the creeks during the NE monsoon is less than during the SW monsoon. If this is true, then the maximum nutrient recycling should occur during the SW monsoons and the maximum export of nutrients and dissolved organic matter should occur during the NE monsoon. However, actual residence times have not been determined for any of the creeks. An important future research project would be to determine if this nutrient export from the bottom water of the tidal creeks produces coastal phytoplankton blooms

To date there has been no systematic study of nutrients and primary productivity in the tidal creeks of this mangrove ecosystem. This paper is part of a 3 yr study on the Indus River delta mangrove ecosystem. Here, we report the nutrient and phytoplankton dynamics in 2 tidal creeks in the northwest corner of the delta. The significance of bacteria in the flux of organic matter in the tidal creeks is reported in an accompanying paper (Bano et al. 1997, this issue).

\section{MATERIALS AND METHODS}

The 2 creeks in this study, Isaro and Gharo, are interconnected tidal creeks which connect to Phitti Creek, which in turn opens into the Arabian Sea (Fig. 1). Sam-

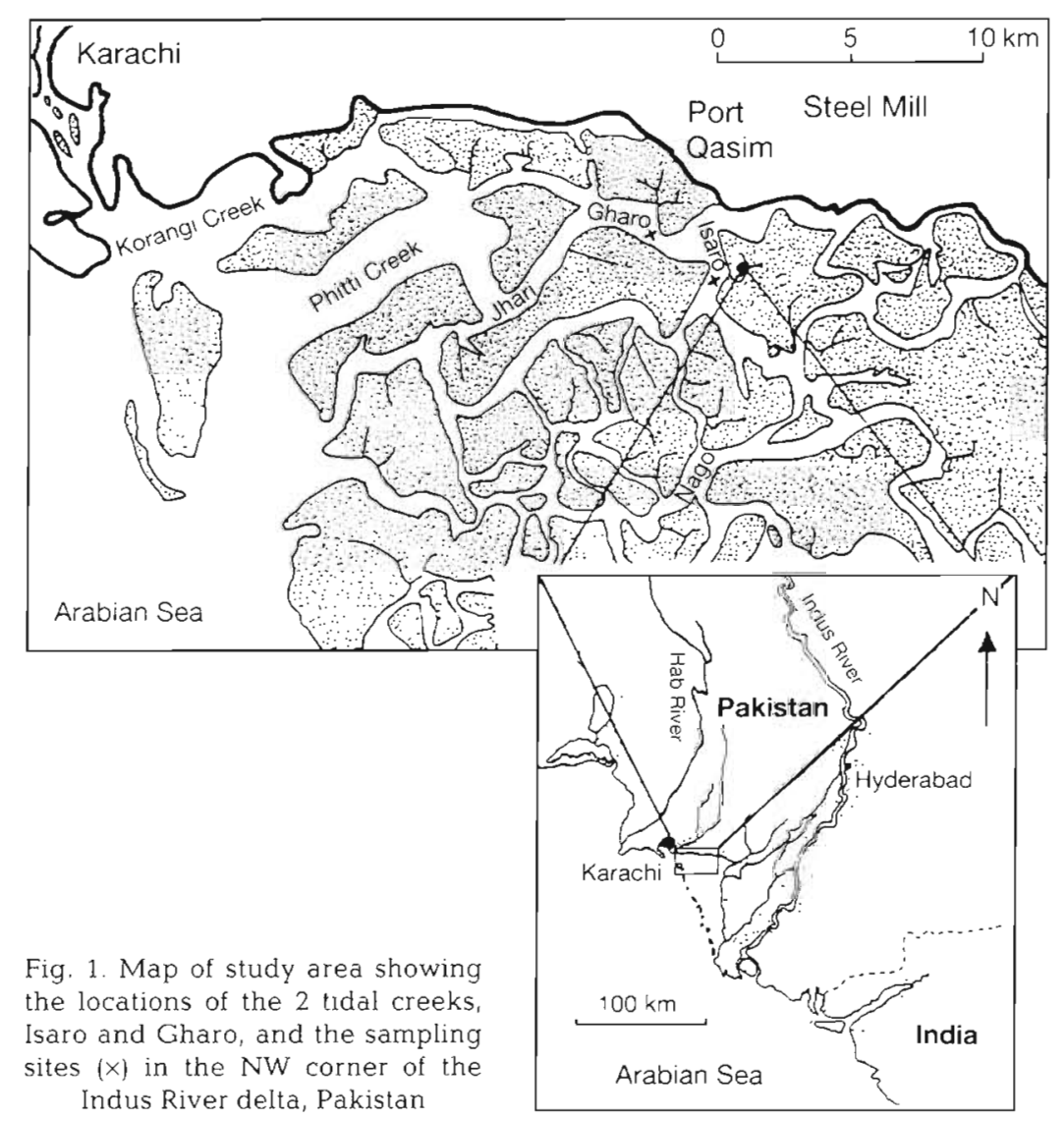


pling was done in the central channel of Isaro and Gharo Creeks and occasionally a side branch of each creek was sampled to determine how much spatial variability existed. Isaro and Gharo Creeks are 3 to $9 \mathrm{~m}$ deep and 100 to $400 \mathrm{~m}$ wide. Salinity ranges from 38 to $40 \%$ during the dry season, but drops to $32-35 \%$ during the rainy season (July and August). Current speeds range from 0.2 to $0.5 \mathrm{~m} \mathrm{~s}^{-1}$ and water movement during a $6 \mathrm{~h}$ tidal excursion is from 5 to $11 \mathrm{~km}$. Our study sites were well beyond the salt wedge at the mouth of the creeks and hence these shallow creeks were well mixed due to tidal action (tidal height differences are from 2 to $4 \mathrm{~m}$ ). The creeks are surrounded by mangrove stands, the dominant species being Avicennia marina. Sampling took place usually during neap tides from 1989 to 1991 with the most frequent (monthly) sampling occurring in 1991. Vertical light profiles were measured with a Li-Cor Li 185 B light meter equipped with a Lambda Instruments 192 S Underwater Quantum Sensor. Water samples were collected from the surface with a clean bucket and above the bottom (2 to 3 m depth) using a 5 l PVC Niskin water bottle.

Subsamples for nutrients were obtained with an acid-washed syringe and gently filtered through combusted $\left(460^{\circ} \mathrm{C}\right.$ for $4 \mathrm{~h}$ ) Whatman GF/F filters (mounted in $25 \mathrm{~mm}$ Millipore Swinex ${ }^{(1)}$ filter holders) into acidwashed polyethylene bottles. Filtered nutrient samples were kept in the dark on ice and returned to the lab within a few hours where they were stored frozen $\left(-20^{\circ} \mathrm{C}\right)$ until they were analyzed a few weeks later. Nitrate and nitrite were analyzed according to Wood et al. (1967) and ammonium according to Slawyk \& Maclsaac (1972). Silicate and phosphate were analyzed by the method of Armstrong et al. (1967) and Hager et al. (1968), respectively.

Subsamples of chlorophyll a (chl a), normally $500 \mathrm{ml}$, were filtered onto Whatman GF/F filters and stored in a desiccator on ice and then stored frozen in the lab a few hours later Chl a was extracted in the dark and cold for $24 \mathrm{~h}$ in $90 \%$ acetone and analyzed spectrophotometrically (Parsons et al. 1984). Since these shallow creeks were always mixed thoroughly from top to bottom because of the large vertical excursions in tidal height, the surface and above-bottom samples were used to obtain an integrated estimate of chl a in the water column, with integration to the $1 \%$ light depth.

Subsamples for suspended load were filtered through preweighed $0.45 \mu \mathrm{m}$ Millipore filters. They were stored in small petri dishes, dried for $24 \mathrm{~h}$ at $60^{\circ} \mathrm{C}$ and reweighed. The difference between the 2 weights equalled the amount of suspended load in the water sample.

Carbon uptake rates were measured in surface samples by adding $2.0 \mu \mathrm{Ci}$ of $\mathrm{NaH}^{14} \mathrm{CO}_{3}$ to triplicate $50 \mathrm{ml}$ samples in borosilicate glass screw-capped test tubes.
After thorough mixing, the tubes were incubated for ca 2 to $3 \mathrm{~h}$ in simulated in situ deck incubators corresponding to 4 light levels $\left(100,30,9\right.$ and $\left.1 \% I_{0}\right)$ which were achieved with different layers of neutral density screening. Samples were cooled with surface seawater. Incubations were terminated by filtration ( $<100 \mathrm{~mm} \mathrm{Hg}$ ) onto Whatman GF/F filters. Filters were placed into scintillation vials containing $0.2 \mathrm{ml}$ of $0.5 \mathrm{~N}$ $\mathrm{HCl}$, which removed inorganic ${ }^{14} \mathrm{C}$. Aquasol II scintillation fluor $(10 \mathrm{ml})$ was added to each vial. Zero time blanks were used to correct for cell and bottle adsorption of ${ }^{14} \mathrm{C}$. Samples were counted on a Beckman liquid scintillation counter and quench correction was by using the channels-ratio method. Carbon uptake rates were determined according to Parsons et al. (1984). Hourly productivity rates were converted to daily rates by dividing the total 2 to $3 \mathrm{~h}$ of carbon uptake by the percentage that the incubation period represented of the daily irradiance.

Samples (200 ml) for phytoplankton species analysis were preserved in Lugol's solution (Parsons et al. 1984) and stored in the dark until analyzed. Subsamples $(50 \mathrm{ml})$ were settled (for $24 \mathrm{~h})$ and counted on an inverted microscope.

\section{RESULTS}

None of the 5 nutrients measured in either of the 2 tidal creeks showed a clear seasonal cycle of concentration (Figs. 2 \& 3). From our limited seasonal sampling, nitrogen and silicate never appeared to be limiting for phytoplankton growth; however, phosphate was undetectable once during the bloom on 5 June 1991 in Isaro Creek. Several times in Gharo Creek phosphate was $0.2 \mu \mathrm{M}$. The approximate concentration ranges for the nutrients were: $\mathrm{NO}_{3}=1$ to $8 \mu \mathrm{M}_{i} \mathrm{NO}_{2}=$ 0.5 to $2 \mu \mathrm{M}_{i} \mathrm{NH}_{4}=2$ to $15 \mu \mathrm{M}_{i} \mathrm{PO}_{4}=0.2$ to $2 \mu \mathrm{M}$; and $\mathrm{SiO}_{4}=3$ to $20 \mu \mathrm{M}$. Nutrient concentrations and seasonal patterns were very similar for Isaro Branch (a station in a small narrow branch of the creek; data not shown). The ranges in nutrient concentrations were similar in Gharo Creek (Fig. 3), but the maxima occurred at different times than in Isaro Main (a station in the broader part of the creek), which again supports the idea of no clear seasonal cycle in nutrients. During 2 sampling periods (October and February) there was no apparent diel cycle in nutrient concentrations (data not shown).

The extinction coefficients $(k)$ in these turbid creeks were very high (Fig. 4B, C). In Isaro Main from January to April $k \approx 1 \mathrm{~m}^{-1}$, and then it increased between May and July to $k \approx 2 \mathrm{~m}^{-1}$; during the monsoon rains in August $k \approx 5 \mathrm{~m}^{-1}$ (Fig. $4 \mathrm{~B}$ ). It returned to about $1 \mathrm{~m}^{-1}$ for the rest of the season (September to December). The 


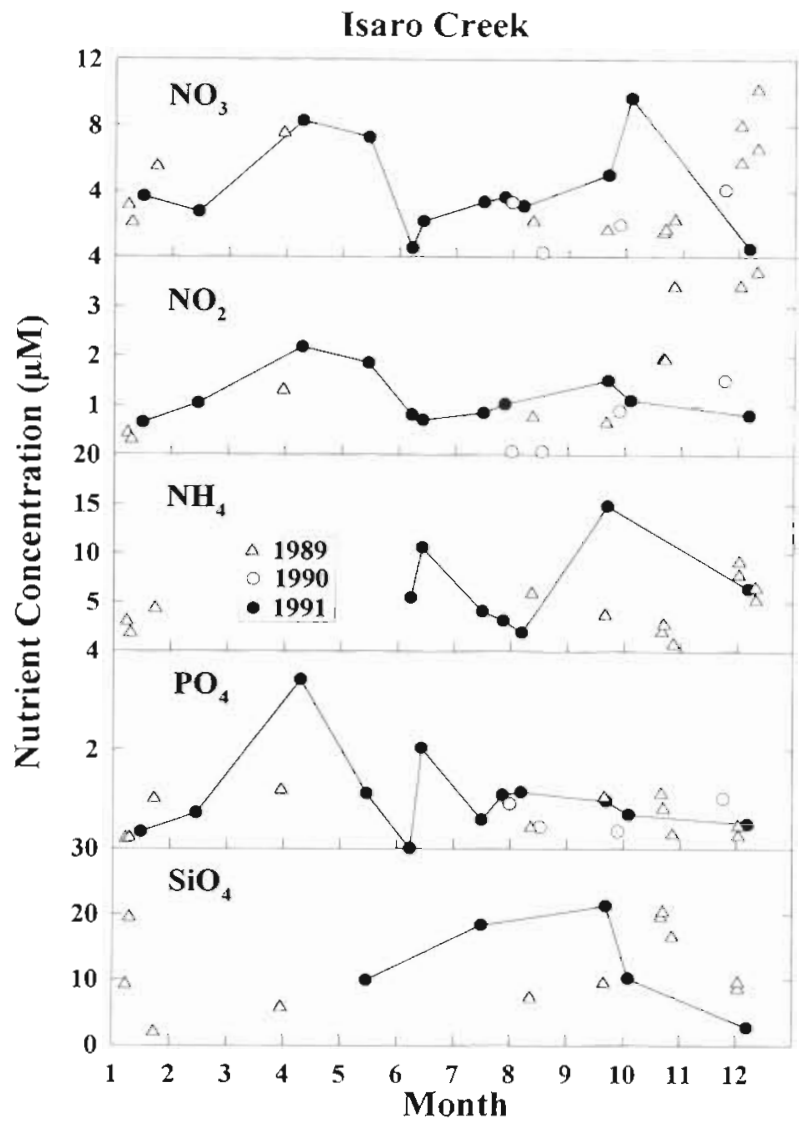

Fig. 2. Seasonal cycle of nutrient concentrations in Isaro Creek during 1989-91. A line joins 1991 data only

seasonal cycle in $k$ was very similar in Isaro Branch (data not shown), but less pronounced in Gharo Creek (Fig. $4 \mathrm{C}$ ). The suspended load in Isaro Creek ranged from about 100 to $180 \mathrm{mg} \mathrm{l}^{-1}$ (Fig. 4A).

Chl a was moderate, ranging from about 5 to $25 \mathrm{mg}$ $\mathrm{m}^{-2}$ ( 1 to $4 \mathrm{\mu g} \mathrm{l}^{-1}$ ) and during 2 blooms (13 February 1991 and 5 June 1991) chl a values were 45 and $194 \mathrm{mg} \mathrm{m}^{-2}\left(17.5\right.$ and $\left.41 \mathrm{\mu g} \mathrm{l}^{-1}\right)$, respectively, in Isaro Main (Fig. 5A, B). There was a lack of pronounced blooms in Gharo Creek. There was no difference in surface and near-bottom chl samples, indicating that these 2 creeks were well mixed. The data were insufficient to decipher if there was a seasonal cycle in chl a.

Primary productivity ranged from 0.15 to over $1 \mathrm{~g} \mathrm{C}$ $\mathrm{m}^{-2} \mathrm{~d}^{-1}$ in Isaro Creek (Fig. 5C). There was no definite seasonal cycle, but productivity was higher from January to April compared to August to October (not including the red tide bloom on 13 February 1991 and another large bloom on 5 June 1991). Preliminary size fractionation data showed that the $<0.3 \mu \mathrm{m}$ size fraction contributed little to the total primary productivity.

The dominant phytoplankters were the large pelagic diatoms (mainly centrics) with no apparent seasonality in species composition. The dominant pelagic diatoms were: Eucampia zodiacus, Melosira moniliformis, Schroederella schroederi, Rhizosolenia setigera, Coscinodiscus nodulifera, Coscinodiscus thori, Cerataulina bergoni, Cylindrotheca closterum, Leptocylindrus danicus, Lauderia borealis, Corethron criophilum, Thalassionema nitzschioides, Chaetoceros teres, Chaetoceros decipiens, Chaetoceros densum. Some pennates (mostly benthic species) such as Navicula distans, N. wawrikae, Pleurosigma normanii, Stauroneis membrancea, Gyrosigma spencerii, and Grammatophora marina were present. The dinoflagellate Prorocentrum micans was frequent and Dinophysis chordata was occasionally seen. Up to 7 different species of tintinnids were seen in a 401 sample concentrated through a $20 \mu \mathrm{m}$ mesh net.

\section{DISCUSSION}

The 2 main factors that could limit primary productivity in these mangrove creeks are nutrients and light. The range in nutrient concentrations is similar to ear-

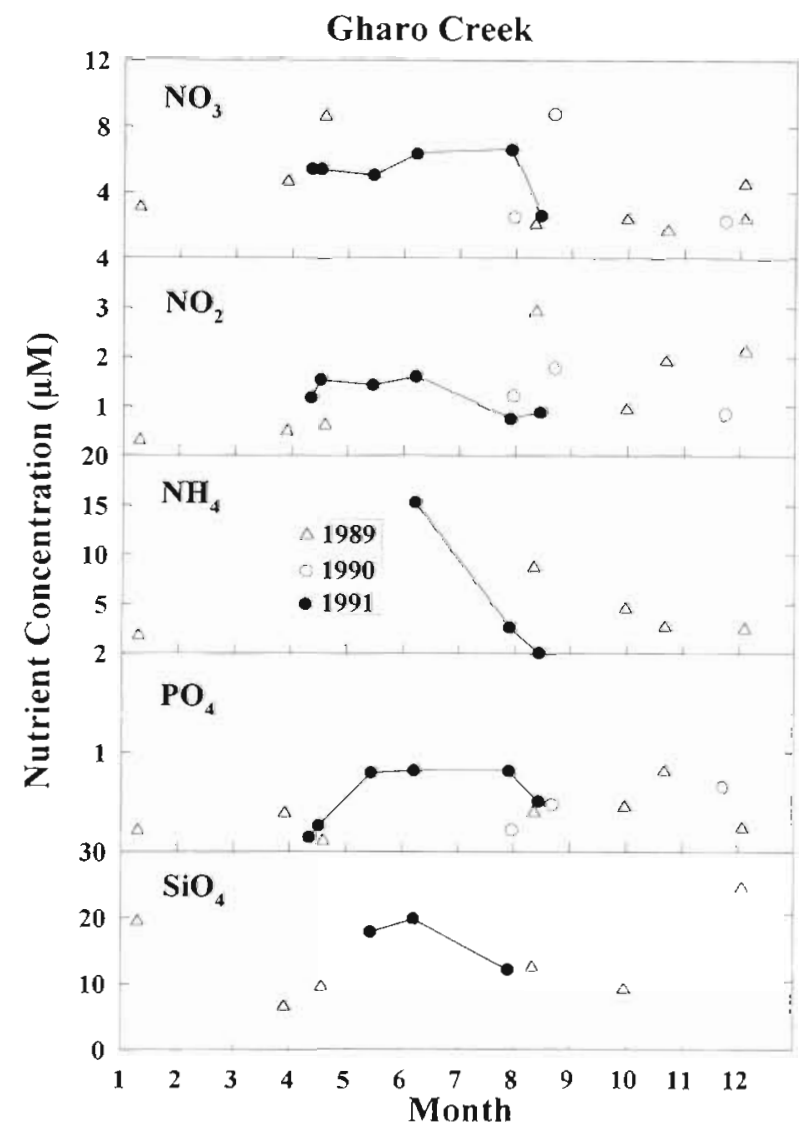

Fig. 3. Seasonal cycle of nutrient concentrations in Gharo Creek during 1989-91. A line joins 1991 data only 


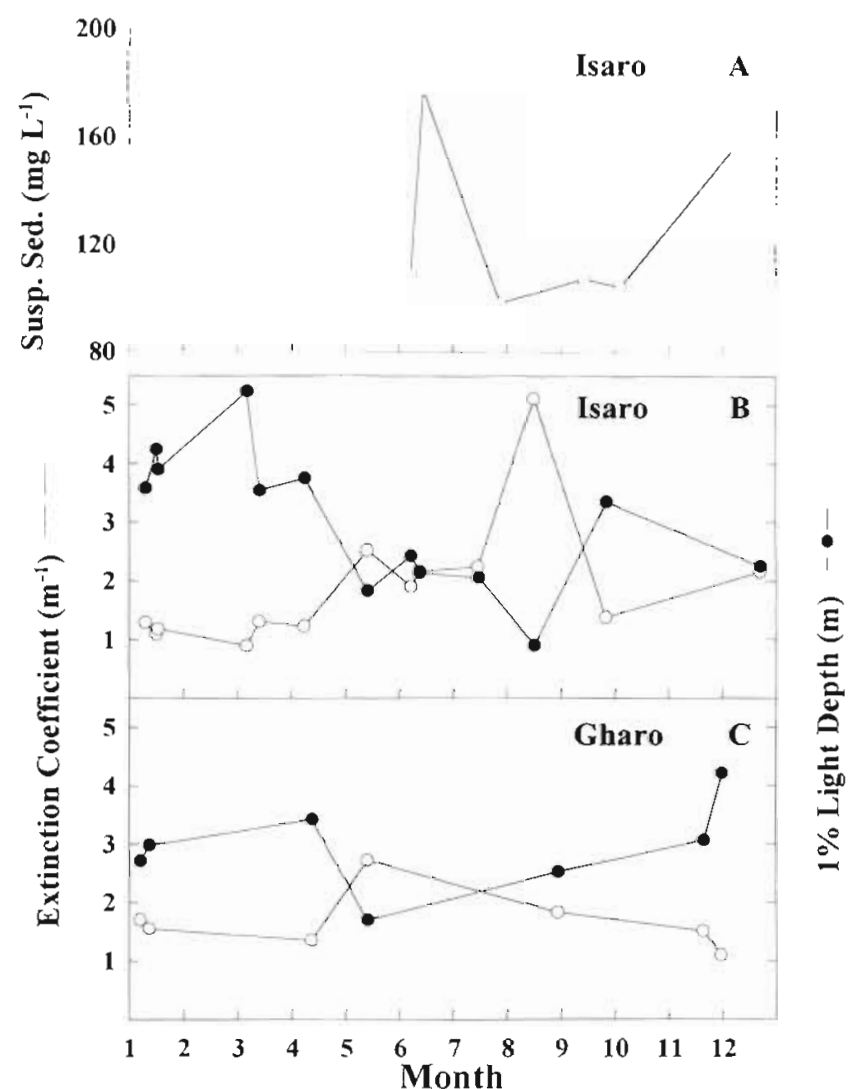

Fig. 4. (A) Suspended load in Isaro Creek in 1991. (B, C) Extinction coefficient and $1 \%$ light depth in Isaro and Gharo Creeks, respectively, in 1991

lier preliminary observations (Harrison et al. 1994). Nitrogen $\left(\mathrm{NO}_{3}+\mathrm{NO}_{2}+\mathrm{NH}_{4}\right)$ and silicate were never limiting. Phosphate was undetectable once (during the bloom on 5 June 1991). Comparison of filtered (sediment removed; the method of analysis used above) and unfiltered samples revealed that the $\mathrm{PO}_{4}$ concentrations were $25 \%$ higher in unfiltered samples than in the filtered ones. This suggests that $\mathrm{PO}_{4}$ is adsorbed to the sediment particles. Similar observations in coastal waters of western Canada revealed that $80 \%$ of this $\mathrm{PO}_{4}$ was biologically available (Yin unpubl. results). Thus bioavailable $\mathrm{P}$ may be higher than the values reported in this paper. The monthly average N:Si:P atomic ratios (Fig. 6) also suggest that phosphate (when N:P> 30) and silicate (when N:Si $<1$ ) might also be potentially limiting nutrients in addition to nitrogen. Silicate could potentially be limiting at times for the dominant primary producers, the large diatoms which tend to be more heavily silicified than smaller ones. Brzezinski (1985) found that the average N:Si ratio for 27 diatoms was 0.9 . Thus $\mathrm{N}$ : Si ratios $>0.9$ could indicate potential Si limitation for these large diatoms.
Since our limited seasonal coverage indicates that nutrients are rarely limiting for primary production. there is an export of nutrients from the creeks to the coastal waters which may stimulate primary production. The NE monsoon winds in winter and spring push the creek surface water downstream, thereby increasing the ebb at the surface and the export of nutrients to the coast. During the NE monsoons, water leaving the mouths of the creeks is transported south by the longshore current, and satellite photographs show a tight band of turbid water close to the coastline (G. S. Qurarishee, National Institute of Oceanography, Pakistan, pers. comm.). Twilley (1988) summarized other studies which show that mangroves export nutrients and DOC (dissolved organic carbon) that increase coastal primary productivity (see his Table 2).

There was a high suspended load in the creeks because the sediments were fine (about $5 \%$ sand, $75 \%$ silt and $20 \%$ clay). These fine sediments are easily suspended by high tidal currents $\left(0.5\right.$ to $\left.1.5 \mathrm{~m} \mathrm{~s}^{-1}\right)$ caused by semi-diurnal tidal ranges of up to $4 \mathrm{~m}$ during spring tides. As a result of this sediment suspension, the extinction coefficients were very high $\left(1\right.$ to $\left.2 \mathrm{~m}^{-1}\right)$ and the $1 \%$ light depth ranged from $<1 \mathrm{~m}$ in July and

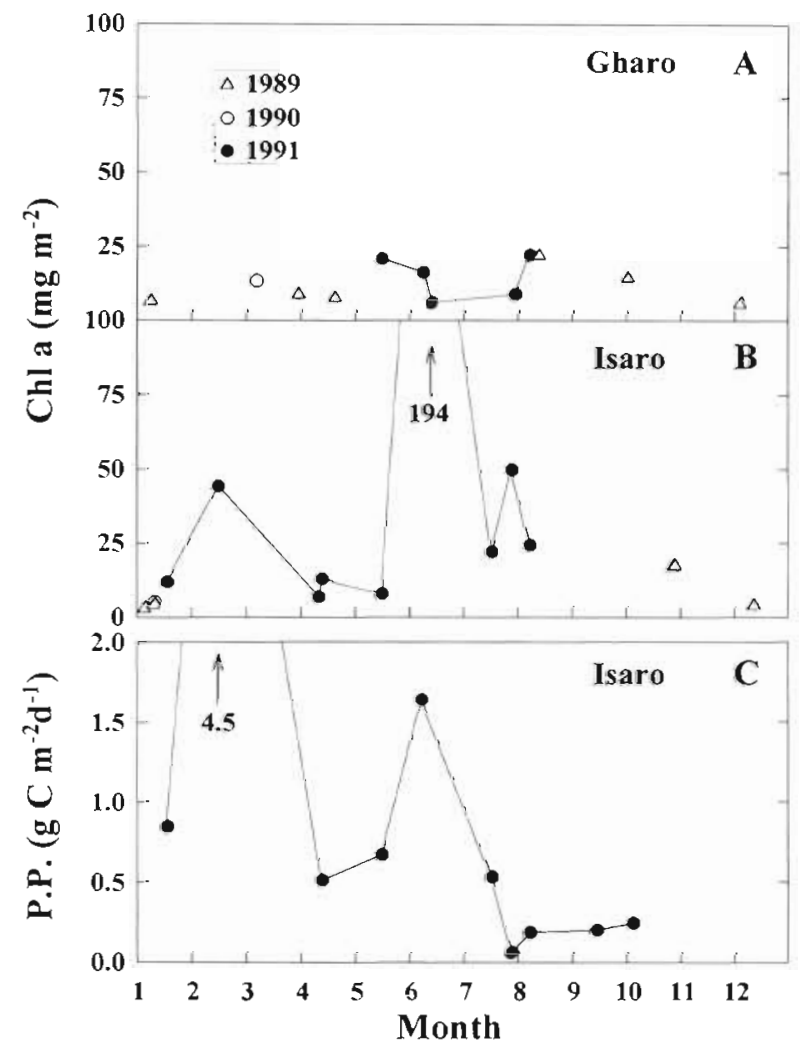

Fig. 5. (A, B) Integrated chl a in Gharo and Isaro Creeks, respectively, during 1989-91. (C) Primary productivity in Isaro Creek during 1991. Line joins 1991 data only 

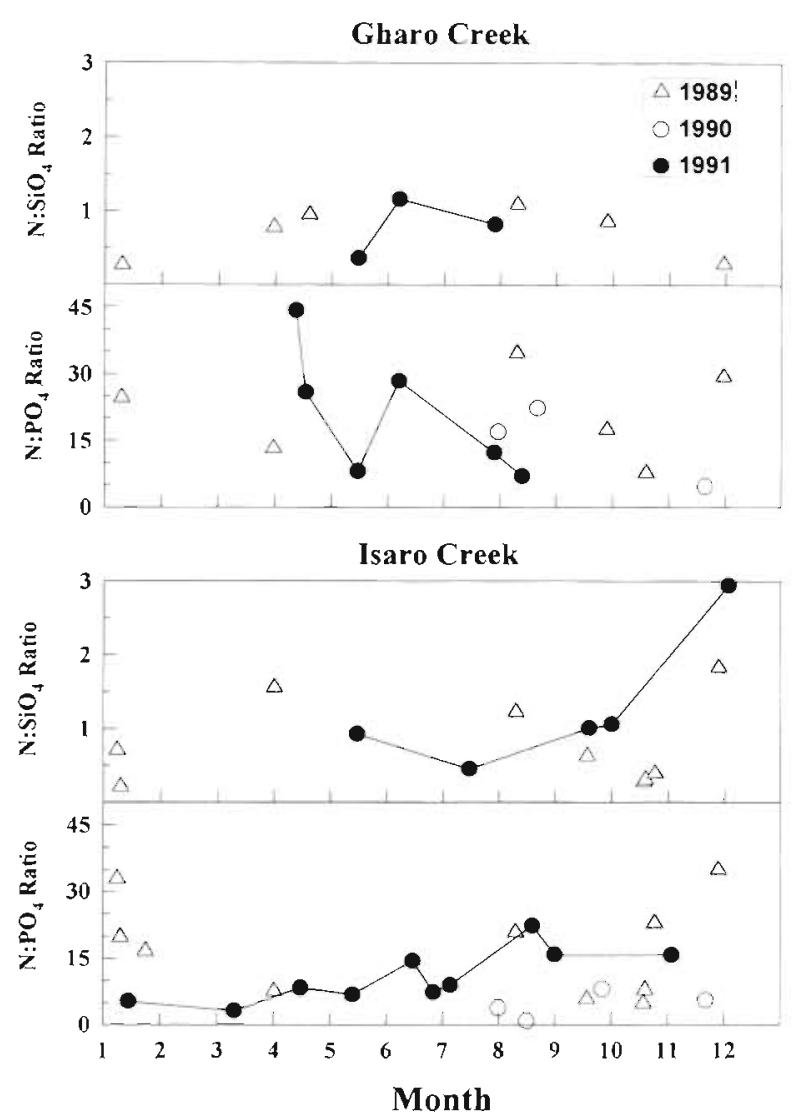

Fig. 6. Average monthly nutrient ratios (by atoms) in Isaro and Gharo Creeks during 1989-91. A line joins 1991 data only

August (the rainy season) to about $4 \mathrm{~m}$ in January and February. Consequently, primary productivity appeared to be light-limited throughout the year. Light limitation decreases phytoplankton growth rates which in turn decreases their demand for nutrients, which explains why nutrients are seldom limiting in these creeks. We always sampled during neap tides when the turbidity should be the lowest and the primary productivity the least light-limited, since the resuspension of the clay and silt particles in these very shallow creeks would be minımum. On 2 occasions, in June and January, estimates of primary productivity indicated no difference between neap and spring tides. This comparison between primary productivity values should be made at all months of the year in future studies. Higher primary productivity has been observed during neap tides compared to spring tides, because sediment particles settle out when tidal energy decreases during neap tides (Wolanski et al. 1980). In the Indus delta creeks, the daily tidal excursion is still 1 to $2 \mathrm{~m}$ during neap tides and this tidal energy may be enough to keep the fine clay and silt particles suspended in these shallow creeks.
Chl a values were moderately high and the phytoplankton biomass was composed primarily of large $(>20 \mu \mathrm{m})$ centric diatoms which were probably kept in suspension by the tidal currents. Large diatoms were also the main primary producers in the Ranong mangrove ecosystem in Southeast Asia (UNDP/UNESCO 1991).

Primary productivity was moderately high considering the extreme turbidity of these creeks and considerably higher than coastal rates (Saifullah 1994). In mangrove-dominated estuaries near Goa, India (just south of the Indus delta), the primary productivity values were very similar to those in Pakistan. The highest productivity occurred in the post-monsoon season 10.4 to $1.6 \mathrm{~g} \mathrm{C} \mathrm{m}^{-2} \mathrm{~d}^{-1}$ ) and chl a was 6 to $11 \mu \mathrm{g} \mathrm{l}^{-1}$ in the Mandovi River estuary (Verlencar \& Qasim 1985). The premonsoon period showed intermediate values and the monsoon period had the lowest primary productivity 10 to $\left.0.6 \mathrm{~g} \mathrm{C} \mathrm{m}^{-2} \mathrm{~d}^{-1}\right)$ and the lowest chl a $(0.5$ to $5 \mathrm{mg}$ $\mathrm{m}^{-3}$ ).

Bacteria play an important role in the Indus River delta mangrove ecosystem. Bano et al. (1997) found that on average bacterial carbon production was twice as much as primary productivity and was primarily due to attached bacteria. They found that even if all the phytoplankton production was utilized by bacteria it would satisfy only 7 to $20 \%$ of the bacterial carbon production. Likewise, DOC production by phytoplankton (which was not measured) is unlikely to provide much carbon for the bacteria since it is a small fraction of the phytoplankton carbon. Thus, the input of carbon from mangrove detritus must be important in maintaining this high bacterial production.

Most mangrove ecosystems in the world are located in tropical areas with high rainfall and hence biological processes are strongly influenced by rainfall and runoff. The Pakistan mangrove ecosystem is unique because it is located in an area that has an arid climate (<18 cm annual rainfall) and large tidal excursions. Therefore, biological processes in the Pakistan ecosystem are strongly influenced by physical forcing functions such as tidal mixing, severe turbidity, high evaporation and reduced nutrient input from rain and runoff. To better understand the physical-biological coupling in these tidal creeks, future research should focus on: the residence time of water in the creeks as influenced by current speeds and winds; more frequent sampling to determine spring/neap tidal effects and the influence of the flushing event during the monsoon rainy season (July-August) on biological cycles; the effect of nutrient export from the creeks on phytoplankton blooms in the coastal areas; the role of zooplankton grazing in controlling phytoplankton biomass; and quantifying the contribution of phytoplankton primary productivity to total primary productivity (that of phytoplankton, man- 
grove trees, macroalgae and benthic microalgae). Since the Indus River mangroves have been suggested to be salt-stressed and vegetation is much less dense than in high rainfall mangroves, the algal primary producers may play a more prominent part in this arid climate mangrove ecosystem.

Acknowledgements. This research was supported by a grant from the U.S. National Science Foundation \#INT-8818807 to S.I.A.

\section{LITERATURE CITED}

Ahmed SI (1992) Coping with excess salt in their growth environments: osmoregulation and other survival strategies deployed by mangroves. Pak J Mar Sci 1:73-86

Armstrong FAJ, Stearns CR, Strickland JDH (1967) The measurement of upwelling and subsequent biological processes by means of the Technicon Autoanalyzer and associated equipment. Deep Sea Res 14:381-389

Bano N, Nisa M, Khan N, Saleem M, Harrison PJ, Ahmed SI, Azam F (1997) Significance of bacteria in the flux of organic matter in the tidal creeks of the mangrove ecosystem of the Indus River delta. Mar Ecol Prog Ser 157:1-12

Brzezinski M (1985) The Si:C:N ratio of marine diatoms: interspecific variability and the effect of some enviromental variables. J Phycol 21:347-357

Hager SW, Gordon LI, Park PK (1968) A practical manual for the use of Technicon Autoanalyzer in seawater nutrient analysis. A final report to B.C.F. (Bureau of Commercial Fisheries), contract 14-17-0001-1759, Ref. 68-33. Oregon State Univ Dept of Oceanography, Corvallis

Harrison PJ, Snedaker SC, Ahmed SI, Azam F (1994) Primary producers of the arid climate mangrove ecosystem of the

Editorial responsibility: Jed Fuhrman (Contributing Editor), Los Angeles, California, USA
Indus River delta, Pakistan: an overview. Trop Ecol 35; $155-184$

Khan SA (1966) Working plan of the Coastal Zone Afforestation Division from 1963-64 to 1982-83. Government West Pakistan, Agriculture Dept, Lahore

Parsons TR, Maita Y, Lalli CM (1984) A manual of chemical and biological methods for seawater analysis. Pergamon Press. Oxford

Saifullah SM (1994) Seasonal and spatial distributions of chlorophyll in the North Arabian Sea bordernng Pakistan. Pak J Mar Sci 3:25-30

Schubel JR (1984) Esturine circulation and sedimentation: an overview. In: Haq BU, Milliman JD (eds) Marine geology and oceanography of Arabian Sea and coastal Pakistan. Van Nostrand Reinhold Co, New York, p 114-136

Slawyk G, MacIsaac JJ (1972) Comparison of two automated ammonium methods in a region of coastal upwelling. Deep Sea Res 19:521-524

Twilley RR (1988) Coupling of mangroves to the productivity of estuarine and coastal waters. In: Jansson BO (ed) Coastal-offshore ecosystem interactions. Springer-Verlag, Berlin, p 155-180

UNDP/UNESCO (1991) The integrated multidisciplinary survey and research programme of the Ranong mangrove ecosystem. Final report. UNDP/UNESCO Regional Project. Research and its applications to the management of the mangroves of Asia and the Pacific (RAS/86/120)

Verlencar XN, Qasim SZ (1985) Particulate organic matter in the coastal and estuarine waters of Goa and its relationship with phytoplankton production. Estuar Coast Shelf Sci 21:235-242

Wolanski E, Jones E, Bunt JS (1980) Hydrodynamics of a tidal creek-mangrove swamp system. Aust J Mar Freshwat Res $31: 431-450$

Wood ED, Armstrong FA, Richards FA (1967) Determination of nitrate in seawater by cadmium-copper reduction to nitrite. J Mar Biol Assoc UK 47:23-31

Submitted: October 10, 1996; Accepted: May 28, 1997

Proofs received from author(s): September 9, 1997 